\title{
NPIPB8 wt Allele
}

National Cancer Institute

\section{Source}

National Cancer Institute. NPIPB8 wt Allele. NCI Thesaurus. Code C140039.

Human NPIPB8 wild-type allele is located in the vicinity of $16 \mathrm{p} 11.2$ and is approximately $34 \mathrm{~kb}$ in length. This allele, which encodes nuclear pore complex-interacting protein family member B8 protein, may play a role in nuclear transport. 